$\xi^{2}=-1$

\title{
Application of vertical electrical sounding (VES) for groundwater exploration in Onitsha and environs, Nigeria
}

\author{
Osele, C.E ${ }^{1 *}$, Onwuemesi, A.G ${ }^{1}$, Anakwuba, E.K. ${ }^{1}$, Chinwuko, A.I ${ }^{2}$ \\ ${ }^{1}$ Department of Geological Sciences, Nnamdi Azikiwe University Awka, Nigeria \\ ${ }^{2}$ Department of Geological Sciences, Federal University Gusau, Nigeria \\ *Corresponding author E-mail: ujosele4life@yahoo.com
}

\begin{abstract}
Surface geo-electrical survey using vertical electrical sounding (VES) method has been carried out in Onitsha and environs in southwestern part of Anambra state in order to determine the aquifer characteristics and groundwater potential of the area. Eleven vertical electrical soundings were carried out within the area of study using schlumberger array configuration. The interpretation of the vertical electrical sounding (VES) data revealed three to five geoelectric units with depth to the aquiferous layers ranging from 21 to $78 \mathrm{~m}$ and resistivity of the saturated layers varying between 20 and $5600 \mathrm{ohm}-\mathrm{m}$. Aquifer characteristics such as transmissivity and hydraulic conductivity calculated from interpretated VES result ranged from $2.55 \mathrm{~m} 2 /$ day to $29.01 \mathrm{~m} 2 /$ day and $0.03 \mathrm{~m} /$ day to $1.37 \mathrm{~m} /$ day respectively. This result shows that the water saturated sandstone units of the study area is hydrological good and capable of producing optimum groundwater yield. Furthermore, borehole could be drilled at depth between 40 and $110 \mathrm{~m}$ in the area for sustainable water supply and hydrochemical study carried out to determine the water quality for domestics and municipal purposes.
\end{abstract}

Keywords: Aquifer; Aquifer Characteristics; Geoelectric Layer; Onitsha and Vertical Electrical Sounding.

\section{Introduction}

Vertical electrical sounding method is one of the surface geoelectrical surveys used in prospecting for groundwater. Several Geophysicists and researchers including Emenike (2001), Onwuemesi et al. (2006), Anakwuba et al., (2014) and Anizoba et al. (2015) have reported its efficiency and effectiveness in prospecting for groundwater, fresh water/ saline water boundary predication and contaminant plumb predication. However, this study is centered on the use of vertical electrical sounding in prospecting for groundwater in Onitsha and environs.

The study area lies within latitudes $06^{\circ} 47^{1} \mathrm{~N}$ to $06^{\circ} 53^{1}$ and longititudes $06^{\circ} 07^{1}$ to $06^{\circ} 12^{1} 30^{11 \mathrm{E}}$ in southwestern part of Anambra State, Nigeria. It covers an area of about $121 \mathrm{~km}^{2}$ (Fig.1). The study area covers some part of Onitsha North, Anambra East, Oyi and Idemili North local Government Areas of Anambra State. It is good to note that, Onitsha has been of high economic activity in Nigeria and West African region and its attendant high population coupled with subsequent cases of bore- hole failures have resulted in massive demand for potable and sustainable water supply for both municipal and domestic purposes. Hence, the need for proper groundwater development and management in the area becomes imperative, since it is readily available though in varying quantities.
The research is aimed at determining depths to potential aquifers in the area and their hydraulic characteristics in order to establish a geophysical data that will serve as guide line for exploration and exploitation of groundwater in the region. This would be achieved by using the vertical electrical sounding method in conjuction with available lithologic logs from the area. The method for the study was chosen because of its excellent vertical resolution and good depth sensitivity, simple instrumentation, easy field logistics and relatively economical, (Zhody et al, 1974).

\subsection{Geologic setting}

The study area lies within the Anambra Basin in the Lower Benue Trough tectonic unit. Anambra Basin is a synclinal structural depression and one of the intracraton basins in Nigeria located in south central Nigeria. It is bounded to the north by Bida Basin and Northern Nigerian Massif, to east by Benue Trough, to the west by West African Massif and to the southwestern by Niger Delta Complex (Whiteman, 1982). The basin is a Crateacous basin having almost a roughly triangular shape (Nwajide, 1996) with a total sediment thickness of about 2500m (Reyment, 1965) covering an area of about 40,000 sq km. Anambra Basin is characterized by enormous lithologic heterogeneity in both lateral and vertical extensions derived from a range of paleoenvironmental setting. 

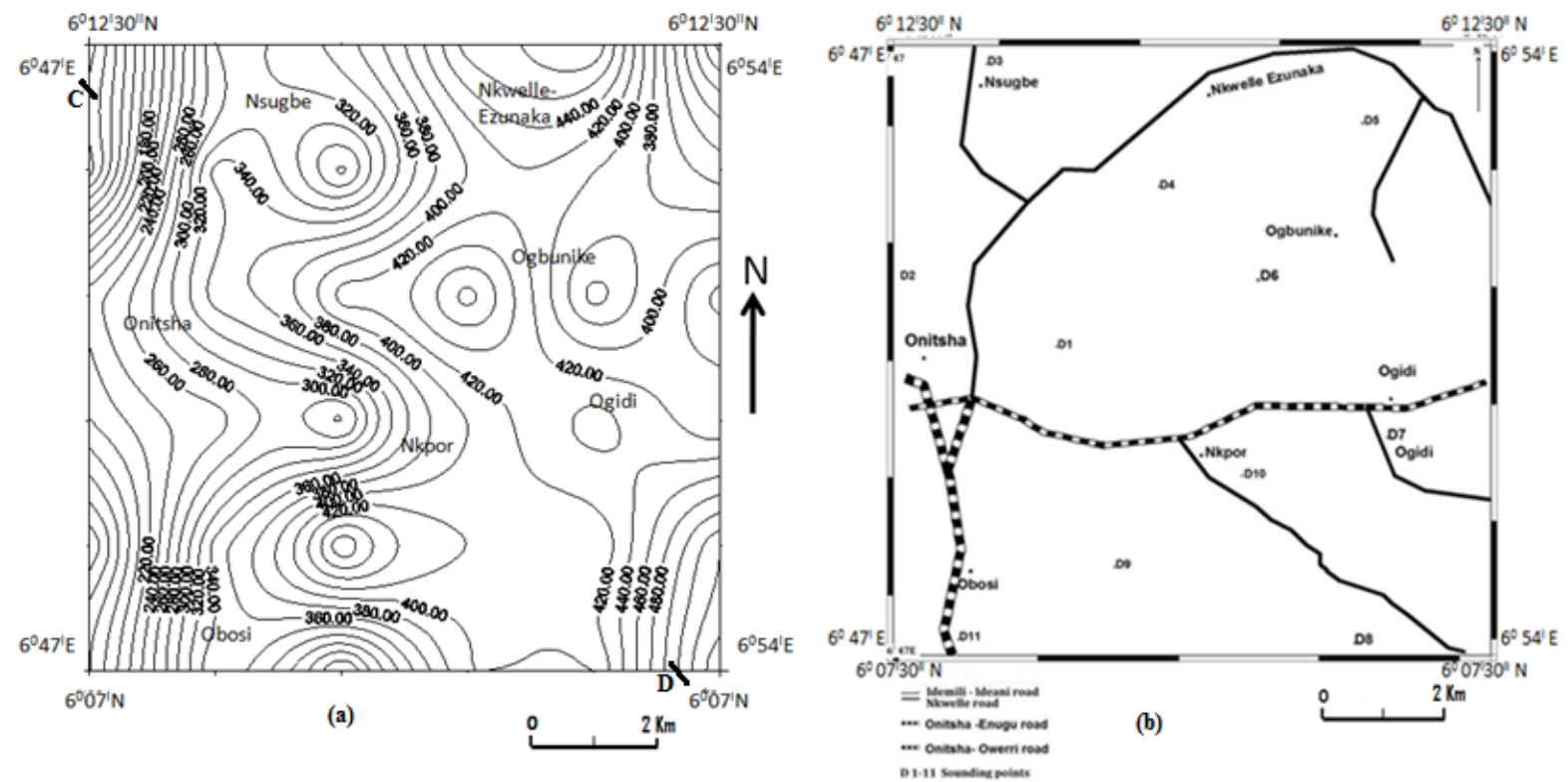

Fig. 1: Base Map: (A) Topographic Map of the Study Area (B) Accssibility Map and VES Points of the Study Area.

Anambra Basin is mainly held to have originated after the Santonian folding and uplift of the Abakaliki region during Campanian to Mid Eocene which resulted in shifting of the depocentre into Anambra Plateform and Afikpo region (Obi, et al., 2001). Subsequently, it became an active depocentre (Reyment, 1965). Similarly, notable researchers such as Murat (1972); Ofoegbu (1982) and Burke (1996); have attributed the origin of the basin to the separation of African and South America lithospheric plates and consequent opening of Altanic in early Cretaceous. Sedimentation during the Campanian-Masstrichtian marks the beginning of deposition in the Anambra Basin and also the third cycle of marine inclusion in the Lower Benue Trough (Ehinola et al., 2005). However, some critical factors such as paleomorphology, proximity of sediment source areas and regular incursion of the sea during the Campanian-Eocene and palaeo- circulation pattern (Nwajide et al., 1996) governed deposition within the basin.

\section{Methodology}

When doing resistivity sounding surveys electrodes are distributed along a line, centered about a midpoint that is considered the location of the sounding. The electrode arrangement used in data acquisition was the Schlumberger array of electrodes since it is the most time effective in terms of field work. For a Schlumberger survey, the two current electrodes A and B and the two potential electrodes $\mathrm{M}$ and $\mathrm{N}$ are still, placed in line with one another and centre on some location, but the potential and current electrodes are not placed equidistant from one another. To acquire the resistivity data in the field, current is introduced into the ground through current electrodes and the potential electrodes are then used to quantitatively measure the voltage pattern on the surface resulting from the current flow pattern of the first set of electrodes. The geometry scheme for this array is shown in Fig. 2 .

All electrodes are placed in a line, a uniform distance apart. The Schlumberger array is widely used in geophysical exploration because it is an efficient means of collecting a large number of data points and these observations are sensitive to the lateral position and depth characteristics of the resistivity distribution.

Eleven resistivity soundings were carried out with maximum separation of current electrodes of 300 meters. The location of soundings is shown in Fig. 1. Data were collected with an ABEM SAS 300 terrameter and SAS 2000 Booster. Survey lines were located along existing roads and paths avoiding physical obstacles like buildings and fences. Sounding data were interpreted using IX1D software and curve matching which leads to geologically reasonable layer structured models that may be accepted or modified in order to agree with available geological information. This approach has been applied extensively in groundwater exploration Singh (2005); Onwuemesi et al. (2006), Soupios et al. (2007), Anudu et al. (2008), Oseji et al. (2009), Okoro et al. (2010), Ezeh (2011), Anakwuba et al. (2014), Anizoba et al. (2015 and others).

(A)

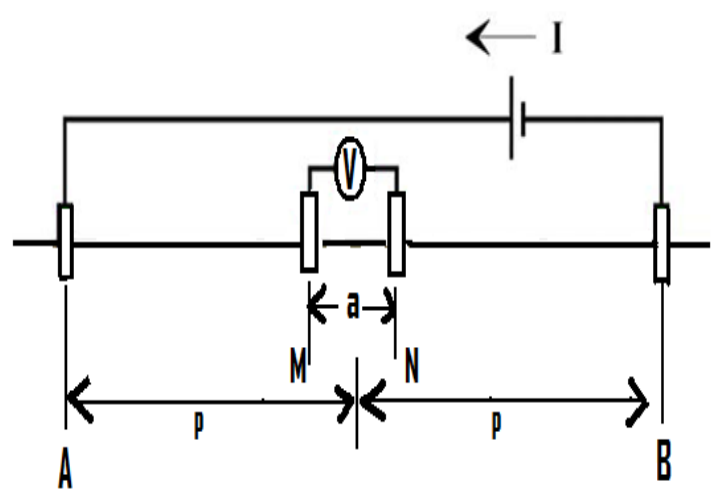

(B)

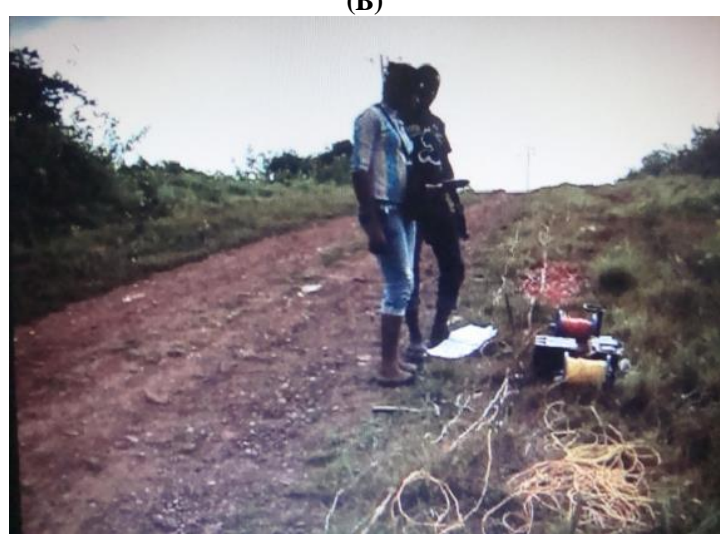

Fig. 2: Schlumberger Array: (A) Sketch Diagram (B) Field Layout in the Study Area. 


\section{Result presentation}

\subsection{Geo-electric section}

In Trans-Nkisi Federal Housing 33 Onitsha (VES 1), Federa Government Girls' College Onitsha (VES 2) and Nkwelle- Ezunaka (VES 5) KH type curve was obtained. The geoelectric units indicate a sequence of lithologies including a lateritic top layer, dry sandstone, shale and water saturated sandstone layer. The thicknesses and corresponding layer resistivities are presented in Table 1 and Fig. 3.

Also within Nkwelle-Ezunaka, HK curve type was obtained (Table 1). The geoeletric unit depicts four layers including top layer of laterite, shale, dry sandstone and water saturated sandstone. Thickness and resistivity values are shown in Table 1. In Nsugbe, the vertical electrical sounding (VES 3) curve type is QHK type
(Fig. 3). It delineates five layers including a top layer of siltstone with boulders, dry sandstone, shale, water saturated sandstone and shale. Table 1 shows the thicknesses and resistivity values of the VES points.

More so, in Nkpor Uno, Nkpor Agu and Obosi, the VES curves are of K type (Table 1). The geoelectric units depict three layers; top layer of laterite, sandstone and water saturated sandstone. A QQ curve type was obtained in Ogbunike (VES 6). It depicts four layers of top laterite, shaley sandstone, water saturated sandstone and shale (Table 1).

Within the Southern part of the study area, the geoelectric units obtained show three to four layers. The curve types for Ogidi (VES 7) and Nkpor main market (VES 10) is HK (Table 1). The inferred lithologies include top laterite layer, shale, dry sandstone and water saturated sandstone.

Table 1: Model Parameters of VES 1-13

\begin{tabular}{|c|c|c|c|c|c|}
\hline VES Name & Layer & Apparent Resisitivity & $\operatorname{Depth}(\mathrm{m})$ & Thickness (m) & Inferred Lithology \\
\hline & 1 & 165 & 1.5 & 1.5 & Lateric top layer \\
\hline \multirow{4}{*}{$1-\mathrm{KH}$} & 2 & 3828.5 & 7 & $1.5-7$ & Dry sandstone \\
\hline & 3 & 299.4 & 20.6 & $7-20.6$ & Shale \\
\hline & 4 & 1450 & Base not & Reached & Water saturated sandstone \\
\hline & 1 & 145 & 1.6 & 1.6 & Lateritic top layer \\
\hline \multirow[t]{4}{*}{$2-\mathrm{KH}$} & 2 & 3217 & 34 & 32.4 & Dry sandstone \\
\hline & 3 & 103 & 37.3 & 3.3 & Shale \\
\hline & 4 & 2664 & Base not & Reached & Water saturated sandstone \\
\hline & 2 & 2032 & 10 & 8.8 & Shaley sandstone \\
\hline \multirow[t]{4}{*}{3 - QHK } & 3 & 923 & 25 & 15 & Water saturated sandstone \\
\hline & 4 & 149 & 68 & 43 & Shaley sandstone \\
\hline & 5 & 32 & Base not & Reached & Shale \\
\hline & 1 & 396 & 3 & 3 & Laterite \\
\hline \multirow[t]{3}{*}{4 - HK } & 2 & 158 & 4.7 & 1.7 & Shale \\
\hline & 3 & 6281 & 65 & 60.3 & Dry sandstone \\
\hline & 4 & 1482 & Base not & Reached & Water saturated sandstone \\
\hline \multirow[t]{4}{*}{$5-\mathrm{KH}$} & 2 & 380 & 26 & 23 & Dry sandstone \\
\hline & 3 & 280 & 45 & 19 & Water saturated sandstone \\
\hline & 4 & 350 & Base not & Reached & Shaley sandstone \\
\hline & 1 & 680 & 4.6 & 4.6 & Laterite \\
\hline \multirow[t]{4}{*}{$6-\mathrm{QQ}$} & 2 & 45 & 30 & 24.4 & Shale \\
\hline & 3 & 20 & 53 & 23 & Water saturated sandstone \\
\hline & 4 & 0.73 & Base not & Reached & Shale \\
\hline & 1 & 1155 & 2.6 & 2.6 & Laterite \\
\hline \multirow[t]{4}{*}{7 - HK } & 2 & 187 & 4 & 1.4 & Shale \\
\hline & 3 & 6234 & 60 & 56 & Dry sandstone \\
\hline & 4 & 1897 & Base not & Reached & Water saturated sandstone \\
\hline & 1 & 348 & 4 & 4 & Laterite. \\
\hline \multirow[t]{3}{*}{$8-\mathrm{K}$} & 2 & 1046 & 54.3 & 50.3 & Dry sandstone. \\
\hline & 3 & 693.53 & Base not & Reached & Water saturated sandstone. \\
\hline & 1 & 720.53 & $0-9$ & 9 & Laterite. \\
\hline \multirow[t]{2}{*}{$9-\mathrm{K}$} & 2 & 1262.6 & $9-78$ & 69 & Dry sandstone \\
\hline & 3 & 680.27 & Base not & Reached & Water saturated sandstone \\
\hline \multirow{3}{*}{10 - HK } & 3 & 5920 & 67 & 60 & Dry sandstone \\
\hline & 4 & 1365 & Base not & Reached & Water saturated sandstone \\
\hline & 1 & 449 & 2 & 2 & Laterite \\
\hline \multirow[t]{2}{*}{$11-\mathrm{K}$} & 2 & 9023 & 35 & 33 & Dry sandstone \\
\hline & 3 & 5600 & Base not & Reached & Water saturated sandstone \\
\hline
\end{tabular}




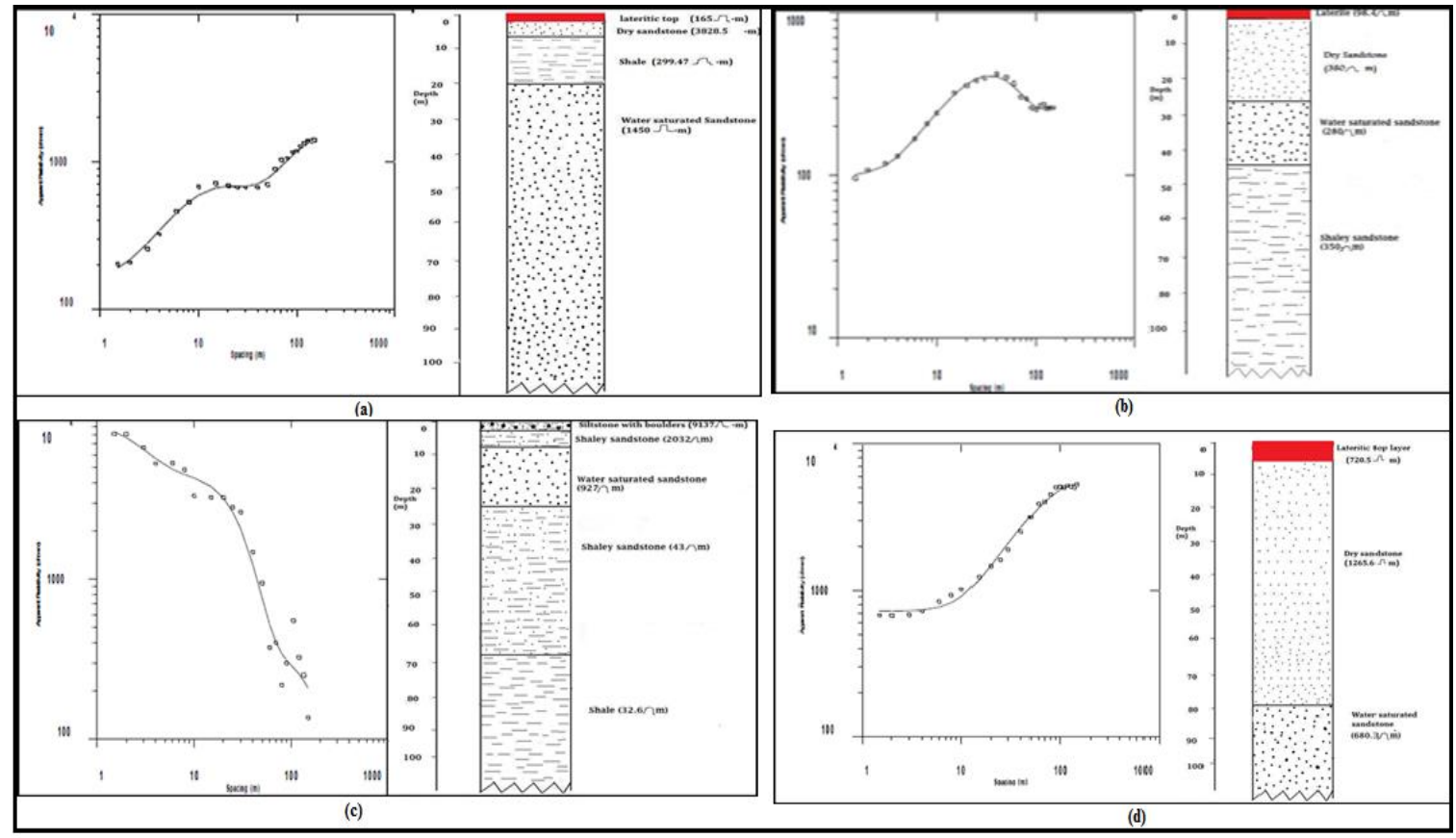

Fig. 3: Sounding Curves and Geo-Electric Units: (A) VES 1 (B) VES 5 (C) VES 3 (D) VES 9.

\subsection{Correlation of geoelectric sections}

A profile along NW-SE and NE-SW were taken inorder to determine the relative relationship within the study area using geoelectric sections. As a result, the correlation along NW-SE was modeled (Fig. 4a) and it shows that the thickness of laterite within $\mathrm{D}_{8}$ (Nkwelle-Ezunaka area) is high compare with $D_{2}$ and $D_{1}$. The depth to water saturated unit is continuous within this region and it has a shallow water depth at 33-Onitsha. Meanwhile, the correlation along NE-SW (Fig.4b) shows high thickness of laterite with deepest depth to saturated unit at $\mathrm{D}_{9}$ (Nkpor-Agu). Generally, the aquiferous units are continuous with various facie changes within the study area.

\subsection{Correlation of VES curves and lithology logs}

The correlation of lithology logs from boreholes within the area of study and geoelectric layers obtained from interpretation of VES reveal the that, in (Fig.5a), the top geoelectric layer having 165 2 $\mathrm{m}$ corresponds with the top litho-layer of light-brownish sandy layer. The second and the third layers of the geoelectric units with $3829 \Omega-\mathrm{m}$ and $299.4 \Omega-\mathrm{m}$ respectively correspond to the second and third litho-layers of dry sandstone and light-grey shaly sandstone. The aquiferous layers both in geoelectric section and litho- $\log$ correlated to the fourth layer. More so, Fig.5b shows that the first geoelectric layers has a resistivity value of $449 \Omega-m$ and thickness of $2 \mathrm{~m}$ corresponding to the litho layer that consists of reddish- brown laterite with thickness of $1.85 \mathrm{~m}$. The second geoelectric layer having $9023 \Omega-\mathrm{m}$ and thickness of $33 \mathrm{~m}$ corresponds to second litho-layer of light-brown dry sandstone while the third layers, both in geoelectric layer and litho-log is the aquiferous layer revealed by its resistivity value of $5600 \Omega-\mathrm{m}$ and lithofacie of whitish medium to coarse grained sandstone.

\subsection{Water table map}

Using the elevation and mean sea level (Table 2), the water table map was plotted and contoured using Surfer 32. The map gives the configuration of the water table within the study area (Fig. 6). Also, cross- sections AB of the water table map (Fig. 6) and CD of the topographic map (Fig. 1a) were used to prepare composite cross-section (Fig. 7). The section shows an intersecting pattern as the water table criss-crosses the topographic surface. This indicates the presence of a river or water body. Comparing it with the drainage features of the area, it is evident that the section ran across River Nkisi in the central part of the study area.

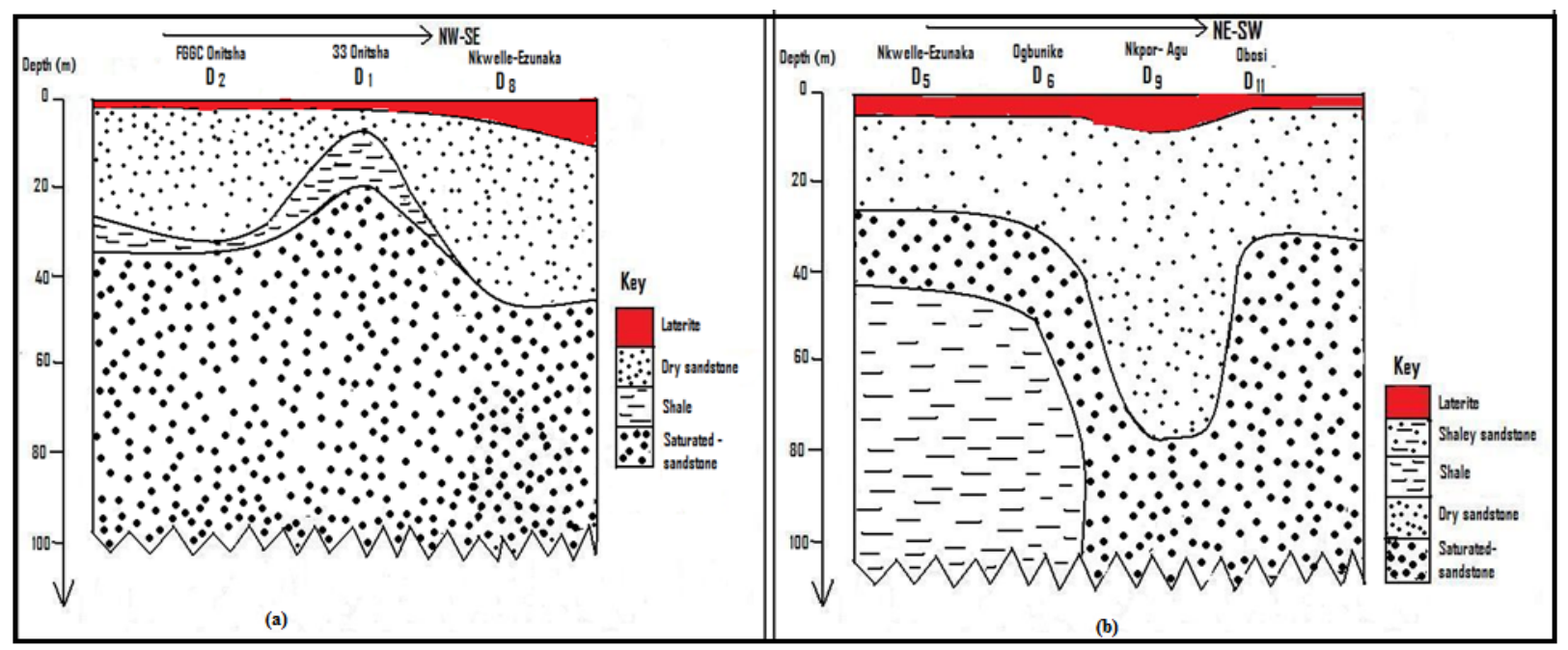

Fig. 4: Regional correlations: (a) NW-SE direction (b) NE-SW direction. 


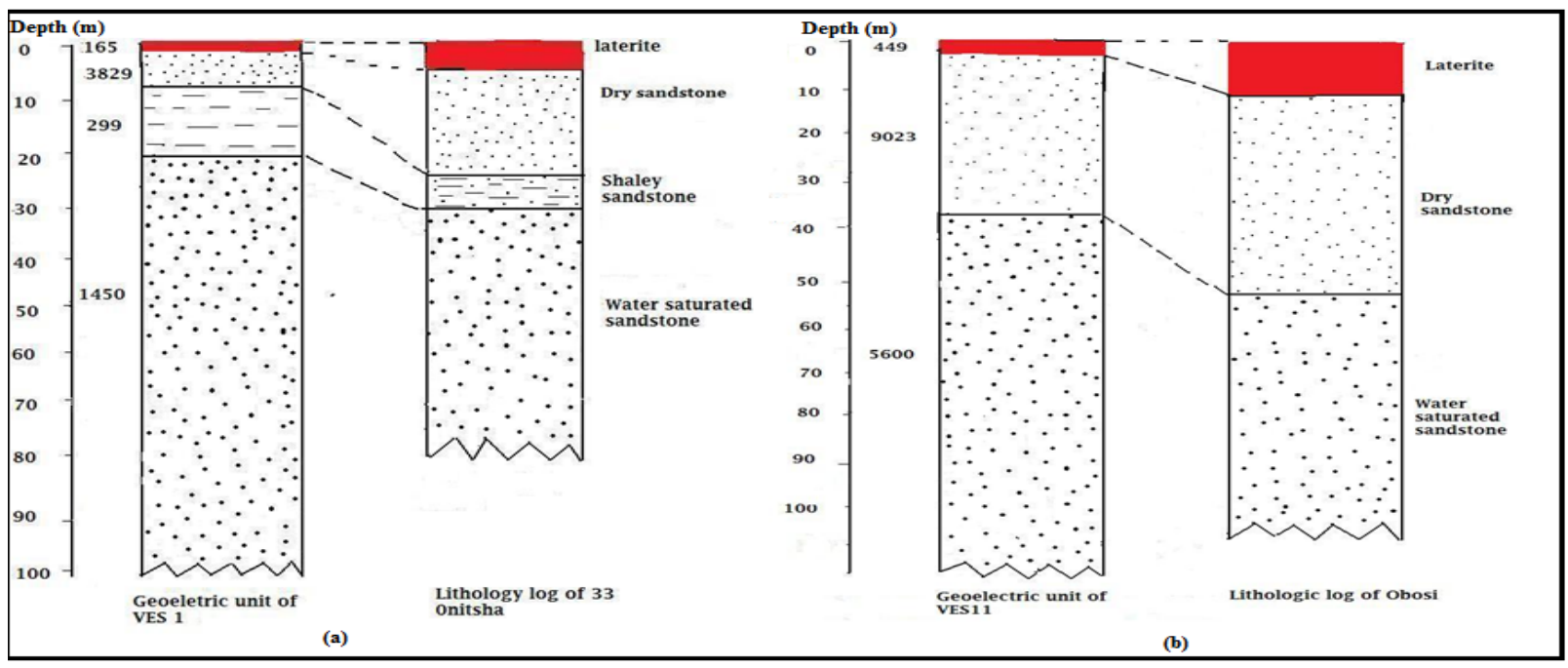

Fig. 5: Correlation of Geoelectric Log and Lithologic Log: (A) VES 1 and Lithologic Log at Obosi (B) VES 11 and Lithologic Log at Obosi.

Table 2: Watertable with Reference to Mean Sea Level (M)

\begin{tabular}{llll} 
& \multicolumn{2}{c}{ Table 2: Watertable with Reference to Mean Sea Level $(\mathrm{M})$} \\
\hline VES NO & Elevation $(\mathrm{m})$ & Water depth $(\mathrm{m})$ & Water depth with reference to mean sea level $(\mathrm{m})$ \\
\hline 1 & 90 & 21 & 69 \\
2 & 102 & 37 & 65 \\
3 & 120 & 55 & 65 \\
4 & 98 & 30 & 68 \\
5 & 124 & 45 & 79 \\
6 & 140 & 54 & 86 \\
7 & 144 & 72 & 72 \\
8 & 143 & 54 & 89 \\
9 & 167 & 78 & 89 \\
10 & 156 & 68 & 88 \\
11 & 93 & 34 & 59 \\
\hline
\end{tabular}

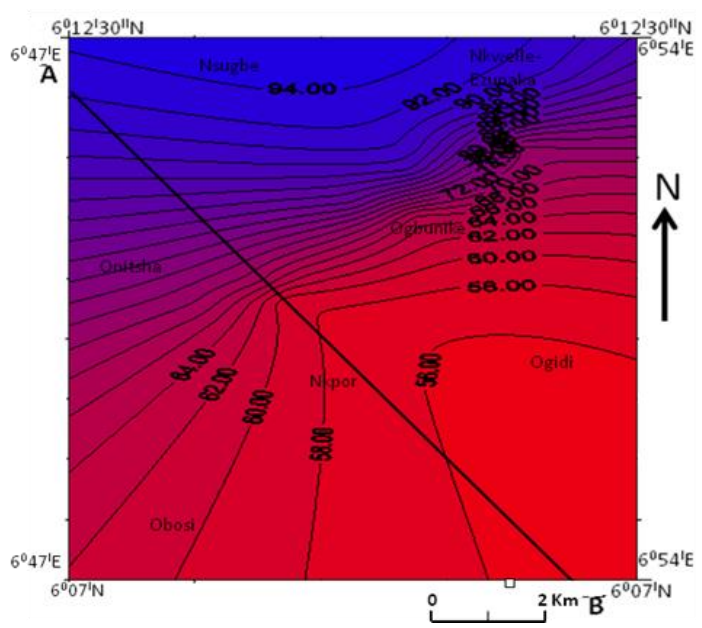

Fig. 6: Water Table Map with Reference to Mean Sea Level of the Study Area (Contour Interval 2m).

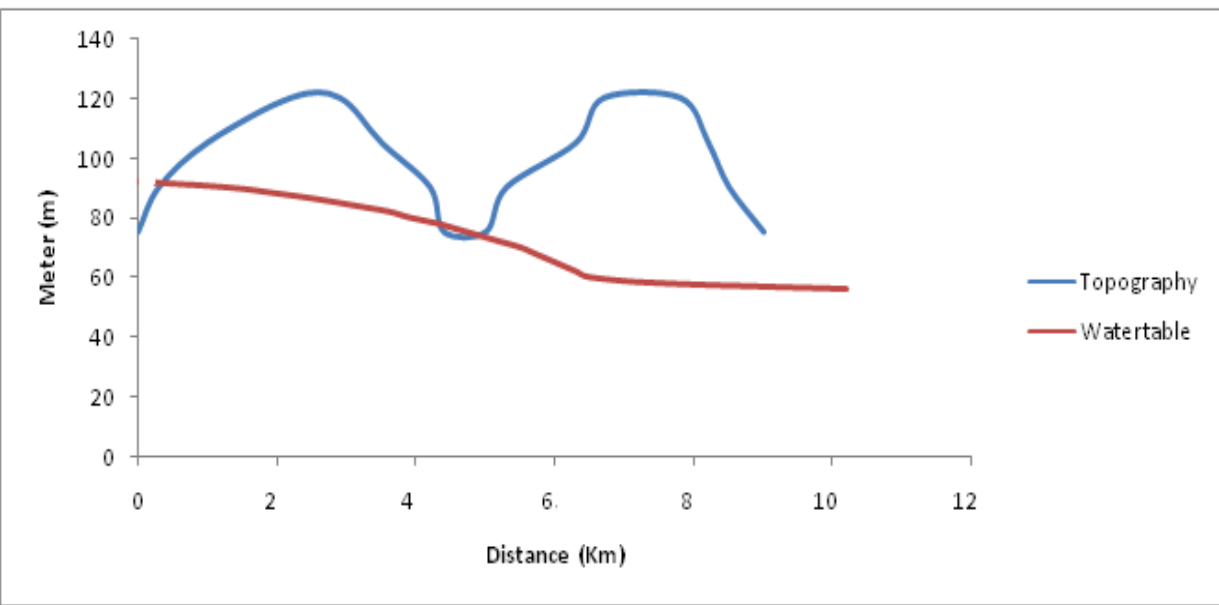

Fig. 7: Composite Cross- Section of Water Table and Topography. 


\subsection{Aquifer parameters}

The aquifer hydraulic characteristics such as hydraulic conductivity $\mathrm{K}\left(\mathrm{m} /\right.$ day) and transmissivity $\mathrm{T}\left(\mathrm{m}^{2} /\right.$ day) were calculated from interpreted VES data using the concept of Dar-zarrouk parameter of Niwas and Sighal, 1981. Calculated hydraulic conductivity $\left(\mathrm{K}_{\mathrm{C}}\right)$ and transmissivity $\left(\mathrm{T}_{\mathrm{C}}\right)$ from interpreted VES data are presented in Table 3. The transmissivity obtained ranges from $2.55 \mathrm{~m}^{2} /$ day to $29.10 \mathrm{~m}^{2} /$ day and the hydraulic conductivity varies from $0.03 \mathrm{~m} /$ day to $1.37 \mathrm{~m} /$ day. These values compared well with those obtained from pumping test analysis of (Eziegbo and Obiefuna, $1995)$ and with those calculated from interpreted VES data of (Okoro et al, 2010). It is good to note that product KO remains fairly constant in areas of similar geologic setting and water quality (Niwas and Sighal, 1981; Onuoha et al, 1988 and Ekwe et al 2006).

Where

$\mathrm{T}_{\mathrm{C}}=$ Calculated transmissivity $\left(\mathrm{m}^{2} /\right.$ day $)$ from VES data; $\mathrm{K}_{\mathrm{C}}=$ Hydraulic conductivity ( $\mathrm{m} /$ day) from VES data.

$\mathrm{O}=$ Electrical conductivity (inverse of resistivity); $\mathrm{R}=$ Transverse resistance $\left(\mathrm{ohm}-\mathrm{m}^{2}\right)$.

$\mathrm{S}=$ Longititudal conductance $\left(\mathrm{ohm}^{-1}\right) ; \rho=$ Resistivity of saturated layer (ohm-m); $\mathrm{b}=$ Thickness of saturated layer $(\mathrm{m})$

Table 3: Aquifer Parameter Calculated From VES Data

\begin{tabular}{|c|c|c|c|c|c|c|c|}
\hline VES locations & $\begin{array}{l}\text { B } \\
(\mathrm{m})\end{array}$ & $\begin{array}{l}\rho \\
(\Omega-m)\end{array}$ & $\begin{array}{l}S \\
\left(\Omega^{-1}\right)\end{array}$ & $\begin{array}{l}\mathrm{R} \\
\left(\Omega-\mathrm{m}^{2}\right)\end{array}$ & $\mathrm{KO}$ & $\begin{array}{l}\mathrm{K}_{\mathrm{c}} \\
\text { (m/day) }\end{array}$ & $\begin{array}{l}\mathrm{T}_{\mathrm{c}} \\
\left(\mathrm{m}^{2} / \text { day }\right)\end{array}$ \\
\hline 1 & 129.4 & 1450 & 0.0892 & 187630 & 0.00002 & 0.12 & 15.51 \\
\hline 2 & 112.7 & 2664 & 0.0423 & 300233 & 0.00006 & 0.22 & 24.79 \\
\hline 4 & 85.0 & 1482 & 0.0574 & 125970 & 0.00002 & 0.03 & 2.55 \\
\hline 5 & 19.0 & 280 & 0.0679 & 5320 & 0.00082 & 0.23 & 4.37 \\
\hline 6 & 97.0 & 20 & 4.8500 & 1940 & 0.01500 & 0.30 & 29.10 \\
\hline 7 & 90.0 & 1897 & 0.0474 & 170730 & 0.00003 & 0.06 & 5.39 \\
\hline 8 & 95.7 & 694 & 0.1379 & 66416 & 0.00024 & 0.17 & 16.27 \\
\hline 9 & 72.0 & 680 & 0.1058 & 48979 & 0.00029 & 0.20 & 14.39 \\
\hline 10 & 83.0 & 1365 & 0.0608 & 113295 & 0.00008 & 0.12 & 9.95 \\
\hline 11 & 115.0 & 5600 & 0.0205 & 644000 & 0.00001 & 0.09 & 10.33 \\
\hline
\end{tabular}

\subsection{Discussion}

Generally, the result of the vertical electrical sounding and the lithologic logs from boreholes in the study area reveal three to five geoelectric layers that are confined. The sandstone units at a depth of 21 to $78 \mathrm{~m}$ constitute the aquiferous units. The saturated layers are confined mostly by shale layers.

However, within the northern part of the study area underlain by Nsugbe sandstone. Depth to water table is averagely $32 \mathrm{~m}$ in Onitsha and Nkwelle, while in Ogbunike and Nsugbe is $54 \mathrm{~m}$. The relative shallow depth in Onitsha and Nkwelle may be due to the influence of elevation which is about $25 \mathrm{~m}$ above sea level and nearness to the source of recharge such as River Anambra and River Nkisi. The resistivity values of the water saturated layers in Onitsha and Federal Government Girls' college Onitsha is $2057 \Omega$ $\mathrm{m}$ on the average while $408 \Omega-\mathrm{m}$ in Nsugbe, Nkwelle and Ogbunike. The low resistivity values of the water saturated layers in Nsugbe, Nkwelle and Ogbunike could be due to the influence of shale intercalations in the sandstone units.

In the southern part of the study area, underlain by the Nanka Sands extending from Ogidi, Nkpor and Obosi, depth to water table ranges from 56 to $78 \mathrm{~m}$. The resistivity values of the water saturated layers vary between $1045 \Omega-\mathrm{m}$ and $1897 \Omega-\mathrm{m}$. The high resistivity values of these layers may be due to the predominance of the sandstone units and availability of fresh groundwater (Emenike, 2000).

The composite cross- section (Fig.7) shows an intersecting pattern as the water table criss-crosses the topographic surface, indicating the presence of a river or water body. Comparing with the drainage map, it is evident that the section ran across River Nkisi in the central part of the study area.

The transmissivity $T_{c}$ and hydraulic conductivity $\mathrm{K}_{c}$ calculated from the interpreted VES data ranges from $2.55 \mathrm{~m}^{2} /$ day to $29.10 \mathrm{~m}^{2} /$ day and $0.03 \mathrm{~m} /$ day to $1.37 \mathrm{~m} /$ day respectively. From the calculations, it is deduced that the groundwater potential of the area is moderately high using the scale of (Driscoll, 1986 and Todd, 1980). Also, these values are defined within the range of observed aquifer parameters obtained from pumping test analysis of (Ezeigbo and Obiefuna, 1995) and those calculated from interpreted VES data of (Okoro et al, 2010).

\section{Conclusion}

Interpretation of vertical electrical sounding and the litho log of boreholes in the study area have been used to determine depth to aquiferous layers in the area. Averagely, depth to water table in the northern part is $26 \mathrm{~m}$ while in the southern part is $75 \mathrm{~m}$. Hence, the depth to water table in the study area is fairly constant within the same lithologic unit but varies only with differences in elevation. Also, the groundwater flow is a reflection of topography. Conclusively, from the range of values of transmissivity and hydraulic conductivity calculated from VES results indelicate that the area is capable of yielding optimum groundwater that will serve for both domestic and municipal purposes.

\section{References}

[1] Anizoba, D. C. Chukwuma, G. O., Chukwuma, E. C., \& Chinwuko, E. C. (2015). Determination of Aquifer Characteristics from Geoelectrical Sounding data in parts of Anambra State, Nigeria. International Journal of Innovation and Applied Studies, 11 (4), 832-843.

[2] Anakwuba, E. K., Nwokeabia, C. N., Chinwuko, A. I., and Onyekwelu, C.U. (2014). Hydrogeophysical assessment of some parts of Anambra basin, Nigeria. International Journal of Advanced Geosciences, 2 (2), 72-81.

[3] Anudu, G.K., Onwuemesi, A.G., Ajaegwu, N.E., Onuba, L.N., and Omali, A.O. (2008). Electrical resistivity investigation for groundwater in the basement complex terrain: a case study of idi-ayunre and its environs, oyo state, southwestern Nigeria. Natural and Applied Sciences Journal, 9 (2), 1-11.

[4] Burke, K. C., (1996). The African Plate. South African Journal of Geology, 99, 341-409.

[5] Driscoll, P. F. G., (1986). Groundwater and wells (2nd Ed.). New York: Johnson division.

[6] Ehinola, O. A.; Sonibare, O. O.; Falode, O. A and Awofala, B. O. (2005). Hydrcarbon Potential and Thermal Maturity of Nkporo Shale from Lower Benue Trough, Nigeria.

[7] Ekwe, A. C.; Onu, N. N. and Onuorah, K. M. (2006). Estimation of aquifer hydraulic characteristics from electrical sounding data: The case of middle Imo River Basin aquifer, Southeastern Nigeria. Journal of spatial hydrology, 6 (2), 23-30.

[8] Emenike, E. A. (2000). Geophysical Exploration for Groundwater in a Sedimentary Envrionment: A case study from Nanka over 
Nanka Formation in Anambra Basin, Southeastern, Nigeria. Global Jour. of Pure and Applied Sciences, 7 (1), 97-110.

[9] Emenike, E. A. (2001). Geophysical Exploration for Groundwater in a Sedimentary Envrionment: A case study from Nanka over Nanka Formation in Anambra Basin, Southeastern, Nigeria. Global Jour. of Pure and Applied Sciences, 7 (1), 56.

[10] Ezeh, C. C. (2011). Geoelectrical studies for estimating aquifer hydraulic properties in Enugu State, Nigeria. International Journal of the Physical Sciences, 6 (14), 3319-3329.

[11] Ezeigbo, H. I. and Obiefuna, G. I. (1995). An evaluation of the groundwater resources of Ogbunike area, Anambra state, Southeatern, Nigeria. Water Resources Journal of Nigeria of Hydrogeologist, 2, 31-41.

[12] Murat, R. C., (1972). Stratigraphy and Paleogeography of the Cretaceous and lower Tertiary in Southern Nigeria in: Dessauvagie, T. F. J. (Ed.)

[13] Nwajide, C. S. and Reijers, T. J. A., (1996). Geology of the Southern Anambra Basin in Reijers,T. J. A.; (Ed.), Selected chapters on geology.

[14] Niwas, S. and Singhal, D. C. (1981). Estimation of aquifer transmissivity from Da-zarrouk parameters in porous media, Journal of hydrology, 50, 393 - 399. http://dx.doi.org/10.1016/00221694(81)90082-2.

[15] Obi, G. C.; Okogbue, C. O. and Nwajide, C. S., (2001). Evolution of the Enugu Cuesta. A tectonically driven erosional process. Global Journal of Pure Applied Sciences, 7, 321-330. http://dx.doi.org/10.4314/gjpas.v7i2.16251.

[16] Okoro, E.I., Egboka, B.C.E., Onwuemesi, A.G. (2010). Evaluation of the aquifer characteristics of Nanka Sands using hydrogeological method in combination with vertical electrical sounding. Journal of $\begin{array}{llllll}\text { Applied } & \text { Sciences, } & 14 & \text { (2), } & 5 & -\end{array}$ http://dx.doi.org/10.4314/jasem.v14i2.57822.

[17] Onwuemesi, A G, Egboka, B.C.E. (2006). 2-D polynomial curve fitting techniques on water table and hydraulic gradients estimations in parts of Anambra Basin, Southern Nigeria. Natural and Applied Applied Sciences Journal, 8 (1\& 2), 6-13.

[18] Oseji, J.O. and Ujuanbi, O. (2009). Hydrogeophysical investigation of groundwater potential in Emu kingdom, Ndokwa land of Delta State,Nigeria. International Journal of Physical Sciences, 4 (5), 275 284.

[19] Onuoha, K. M., and Mbazi, F. C. C. (1988). Aquifer transmissivity from electrical sounding data. The case of Ajali Sandstone aquifers, Southeast of Enugu, Nigeria. In: Ofoegbu C. O.; (Eds), Groundwater and mineral resources of Nigeria, Friedr. Vieweg and John Publishers. http://dx.doi.org/10.1007/978-3-322-87857-1 3

[20] Reyment, R. A. (1965). Aspects of the Geology of Nigeria. Ibadan: University of Ibadan Press.

[21] Singh, K. P. (2005). Nonlinear estimation of aquifer parameters from surfical resistivity measurements. Hydro. Earth Sci. Discuss, 2: 718-726.

[22] Soupios, P. M.; Kouli, M.; Vallianatos, F., Vafidis, A. and Stavroulakis, G. (2007). Estimation of aquifer hydraulic parameters from surficial geophysical methods: A case study of Keritis Basin in Chania (Crete- Greece).Journal of Hydrology, 338: 122-131. http://dx.doi.org/10.1016/j.jhydrol.2007.02.028

[23] Todd, D., (1980). Groundwater hydrology. New York: John wiley and sons Inc.

[24] Whiteman, A. J. (1982). African Geology. Ibadan: University of Ibadan Press, Nigeria.

[25] Wright, J. B., (1968) South Atlantic Continental drift and the Benue Trough. Tectonphysics, 6 (4), 301-310. http://dx.doi.org/10.1016/0040-1951(68)90046-2.

[26] Zhody, A. R.; Eaton, G. I. and Masay, D. R., (1974). Appilcation of subsurface geophysics to groundwater investigation. Technical water resources investigation, Washington Geological Survey. 